Article

\title{
Toward Resilient Water-Energy-Food Systems under Shocks: Understanding the Impact of Migration, Pandemics, and Natural Disasters
}

\author{
Bassel Daher ${ }^{1,2,3, *(D)}$, Silva Hamie ${ }^{4}$, Konstantinos Pappas ${ }^{1,5}$, Mohammad Nahidul Karim ${ }^{1}$ and Tessa Thomas ${ }^{4}$ \\ 1 Texas A\&M Energy Institute, Texas A\&M University, College Station, TX 77843, USA; \\ kostis.pappas@tamu.edu (K.P.); sbmkari@tamu.edu (M.N.K.) \\ 2 Department of Biological and Agricultural Engineering, Texas A\&M University, \\ College Station, TX 77843, USA \\ 3 Institute of Science Technology and Public Policy, Bush School of Government and Public Service, \\ Texas A\&M University, College Station, TX 77843, USA \\ 4 Bush School of Government and Public Service, Texas A\&M University, College Station, TX 77843, USA; \\ silva.hamie@tamu.edu (S.H.); tessie9@tamu.edu (T.T.) \\ 5 Borders \& Migration Lab, Mosbacher Institute for Trade, Economics, and Public Policy, Bush School of \\ Government and Public Service, Texas A\&M University, College Station, TX 77843, USA \\ * Correspondence: bdaher@tamu.edu
}

check for updates

Citation: Daher, B.; Hamie, S.; Pappas, K.; Nahidul Karim, M.; Thomas, T. Toward Resilient

Water-Energy-Food Systems under Shocks: Understanding the Impact of Migration, Pandemics, and Natural Disasters. Sustainability 2021, 13, 9402 https://doi.org/10.3390/su13169402

Academic Editor:

Enrique-Javier Díez-Gutiérrez

Received: 2 July 2021

Accepted: 18 August 2021

Published: 21 August 2021

Publisher's Note: MDPI stays neutral with regard to jurisdictional claims in published maps and institutional affiliations.

Copyright: (c) 2021 by the authors. Licensee MDPI, Basel, Switzerland. This article is an open access article distributed under the terms and conditions of the Creative Commons Attribution (CC BY) license (https:/ / creativecommons.org/licenses/by/ $4.0 /)$.
Abstract: The historic pandemic faced by the international community today boldly demonstrates the complexity and interconnectedness of the resource challenges we must better understand and address in the future. Further complexity is observed when accounting for the impact of compounded shocks related to natural disasters and forced migration around the world. Effectively addressing these challenges requires the development of research that cuts across disciplines and innovates at their interfaces, in order to develop multifaceted solutions that respond to the social, economic, technological, and policy dimensions of these challenges. Water, energy, and food systems are tightly interconnected. They are faced with pressures of varying natures and levels of urgency which need to be better understood, especially as nations work toward achieving the UN 2030 Agenda's Sustainable Development Goals by 2030. This paper will review existing models and knowledge gaps related to water-energy-food (WEF) nexus models, as well as models for quantifying the impact of migration, pandemics, and natural disasters on this resource nexus. Specifically, this paper will: (1) explore the WEF nexus literature and identify gaps in current assessment tools and models; (2) explore the literature on tools and models for predicting the shocks of migration, natural disasters, and pandemics; (3) identify interconnections between water, energy, and food systems and the identified shocks; (4) develop a common framework that provides a road map for integrating those shocks in WEF nexus analysis; (5) provide recommendations for future research and policies moving forward.

Keywords: water-energy-food nexus; migration; resilience; interconnections; sustainable development goals

\section{Introduction}

Global conflicts, economic and political instability, disease, and natural disasters, among other factors, have led to some of the most significant migratory crises in modern history. The United Nations High Commissioner for Refugees [1] estimates there to be 70.8 million forcibly displaced people worldwide, 25.9 million of whom are refugees. More than half of the world's total refugee population originates from Syria, Afghanistan, and South Sudan [1]. The war in Syria, now in its tenth year, has internally displaced 6.2 million Syrians and caused another 5.6 million to flee to other states, the large majority to neighboring countries. According to UNHCR data for April 2020, Turkey hosts 3,643,700 Syrian refugees, Lebanon 910,256, Jordan 656,231, Iraq 247,400, and Egypt 130,074. The 
war in Afghanistan, by comparison, has lasted nearly two decades and caused 2,371,815 Afghans to flee their homes. As of March 2020, Pakistan has hosted 1,420,673 and Iran 951,142 refugees from Afghanistan [2]. The war in South Sudan has internally displaced nearly 4 million people and forced an additional 2,254,341 to seek refuge in neighboring Sudan, Uganda, Ethiopia, Kenya, and the Democratic Republic of the Congo (DRC) $[3,4]$. Countries accepting refugees tend to struggle to provide necessary services to the increasing number of people within their borders. For developing countries, in particular, migration can exert significant pressures on already fragile resource systems. For example, the Middle East and North Africa (MENA) region, facing a sizable gap in accessible water relative to its population, is home to $5 \%$ of the earth's population, but only receives $1 \%$ of the earth's water [5]. The lack of access to water carries additional implications for the agriculture and energy sectors. Water, energy, and food are tightly interconnected: water is needed to harness energy and irrigate crops; energy is needed to extract water and fuel agricultural technology; food is essential for human survival. Countries already facing pressures to provide sufficient water, energy, and food for their citizens are often overburdened by additional resource demands from migrants and refugees.

Pressures on the water, energy, and food resources of developing nations will be further intensified by expected climate change and population growth [6,7]. These effects are "not simply additive: each domain affects the others and causes a cascade of effects which then cause nonlinear impacts" [6] (p. 25). Climate change will increase the frequency and severity of natural disasters, which have and will continue to cause massive flooding in coastal regions in countries with flat topographies (e.g., Bangladesh), forcing millions to flee [8]. Population growth, especially in urban areas, is linked to increases in infectious disease outbreaks [9]. As has been seen with the COVID-19 pandemic, infectious disease outbreaks can have devastating impacts at individual, regional, national, and global levels. The increased pressures on water, energy, and food resources resulting from migration will further add to the complications faced by developing states. In 2015, the United Nations (UN) adopted the 2030 Agenda for Sustainable Development, comprising 17 Sustainable Development Goals (SDGs) for achieving "peace and prosperity, for people and the planet". In the Agenda, the UN recognizes the interdependency of water, energy, and food for attaining "peace and prosperity". Put differently, the 2030 Agenda recognizes that, without achieving "zero hunger", "clean water and sanitation", "affordable and clean energy", and others, countries cannot eliminate poverty and provide a high standard of living for their citizens [10]. While the Agenda recognizes migration as an adaptive strategy through SDG target 10.7, the nature of interconnections among water (SDG 6), energy (SDG 7), food (SDG 2), migration (SDG target 10.7), natural disaster (SDG 13), and pandemics (SDG target 3.3) are yet to be recognized [11,12]. Moreover, the COVID-19 pandemic has led to an unprecedented crisis, with negative impacts on reducing hunger (SDG 2) and promoting health (SDG 3). The pandemic has also had a moderately negative impact on water (SDG 6) and energy (SDG 7), along with a negative health and economic impact on refugees and migrants (SDG 10) throughout the world [13].

If states, developed and developing alike, are to achieve the UN's SDGs by 2030, a better understanding of the relationships between these critical resources, migration, natural disasters, and pandemics is necessary. This paper aims to synthesize a common framework that integrates water-energy-food (WEF) nexus literature with shocks such as migration, natural disasters, and pandemics. Specifically, this paper will: (1) explore the WEF nexus literature and identify gaps in current assessment tools and models; (2) explore the literature on tools and models for predicting the shocks of migration, natural disasters, and pandemics; (3) identify interconnections between water, energy, and food systems and the identified shocks; (4) develop a common framework that provides a road map for integrating those shocks in WEF nexus analysis. 


\section{The Water-Energy-Food (WEF) Nexus: An Overview of the Interconnected Challenges, Models and Assessment Tools, and Existing Gaps}

Siddiqi and Anadon (2011) state that "many...technical processes of harnessing, extracting, and producing energy utilize water. Similarly, water extraction, treatment, distribution, and disposal processes consume energy" [7] (p. 4529). This "interdependency" between water and energy is becoming increasingly recognized by policymakers, who previously treated water and energy as separate sectors. The energy sector relies on water for fuel production and electricity generation; the water sector relies on energy for abstraction, purification, distribution, utilization, and disposal $[7,14]$. Similarly, the agricultural sector depends upon both water and energy: the agrifood industry uses nearly a third of the world's energy and is one of the world's greatest consumers of water $[6,15]$.

\subsection{The WEF Nexus-Background}

The term 'nexus,' by definition, refers to connections linking different elements [16]. The concept of tight interconnectedness across resources such as water, land, food, energy, and environment has gained increasing attention in research and decision-making communities [17]. While the nexus concept initially focused on the security of water, energy, and food supply from the perspective of water [18], this approach can be traced to the World Economic Forum in 2008, where the global challenges related to economic development were recognized from the WEF perspective [19]. According to the World Economic Forum's Global Risks report, the WEF nexus is highly influential in preserving human, social, and political security [20]. The necessity of identifying these interlinkages has grown since the announcement of the 2030 Agenda for Sustainable Development [10]. In spite of the recognition of the importance of adopting a WEF nexus approach, its application remains limited due to several barriers [21]. Some researchers have reported that the introduction of the WEF nexus concept is context-dependent and that generalized use of such terms can be overlapping and ambiguous [22,23]. Further, the term "WEF" brings different meanings to different stakeholders [24]. It can move between Energy-Water-Food (EWF), Food-Energy-Water (FEW) or Water-Energy-Food (WEF), depending upon the focus of research or interest of stakeholders [25]. The scope can be broad, covering themes such as economics, resource security, and climate, or narrow, as in a defined system for which only a few interconnections among the resources are selected [26].

\subsection{Global Trends}

Although the definition and structure of nexus modeling varies by context and research environment, there are essentially two broad categories of consideration [27]. In the first category, the nexus is interpreted as the interconnections among different resource subsystems [28]. This approach aims to identify trade-offs and synergies of resource systems, to internalize social and environmental impacts, and to guide the development of cross-sectoral policies [29]. The interconnection process among these resources includes physical and chemical relations, input and output relations, and the interactions with external factors such as markets, governing institutions, and security issues [30]. In the second approach, the nexus is presented as an analytical means to quantify the functionality of the link or identify the impact or influence of interlinkages [19,31,32]. The Food and Agriculture Organization showed how the coupled behavior of humans and nature can be integrated into the management of natural resources through the nexus approach [33]. In spite of differences in methodologies in all of these categories, both approaches can potentially provide a framework for better decision-making in resource governance by addressing trade-offs and identifying synergies in the WEF nexus.

\subsection{WEF Nexus Models}

WEF nexus models vary depending on the region of interest and critical research questions being addressed. The scale can vary from the local or city level to the global level. The focus of the model can be a combination of only core (WEF) elements, to elements 
affected by land use, emissions, climate, ecosystems, and the economy. Each model can be different in terms of type (e.g., quantitative, simulation, statistical, integrated), purpose (e.g., case study or scenario assessment), temporal variation (e.g., present or future), and data availability (e.g., limited, moderate, or high) [34,35]. The complexity of tools representing each model is dependent largely on research objectives. Many models and decision support tools have been developed in the past decade that focus on different questions at different scales [29,36-43]. Some common limitations appear, including the lack of data availability as well as challenges in connecting different sectoral tools to one another.

\subsection{Research Gaps}

Existing WEF nexus models and tools focus on answering questions related to better management of water, energy, and food resources within defined contextual factors such as local geography, climate, economics, resource demands, or national goals. Few models have the ability of assessing the impact of sudden and significant disruptions to these resource systems which might arise from a drought, flood, cyclone, or other natural disasters. In Asia and Africa, flooding and storms resulting from natural disasters are the main reasons for loss in agriculture [44]. Yet, when compared to uncertainty assessments, the water, energy, and food cross sectoral interactions have been understudied [45]. The loss of agricultural production due to sudden outbreaks of crop epidemic or other disruptions in food demandsupply chains during a pandemic is understudied as a part of integrated water, energy, and food security, even though the inability to access these basic resources due to environmental degradation is identified as one of the major drivers for migration [30,46,47]. Yet, to the authors' knowledge, there is no WEF model or framework that includes migration as a thematic focus, despite the fact that the international institutions have brought to light, several times, the interlinkage between water and migration, food security and migration, and energy and migration [12,46,48].

\section{Migration and the WEF Nexus}

Migration refers to the movement of persons, for various reasons, away from their usual residence within national or across international borders and either temporarily or permanently [49]. Persons or groups of people forced to move from their habitual places to avoid the adverse effects of armed conflict, violence, violations of human rights, human or natural disasters, and who have not crossed an internationally recognized border, are identified as internally displaced persons (IDPs) [49]. However, those who must move to a country other than their country of origin, irrespective of the reasons for migration or legal status, are informally recognized as international migrants [50]. International migrants are identified as refugees with "well-founded fear of prosecution for reasons of race, religion, nationality, social affiliations, political opinion ... and unwilling to return to his/her country of origin" [51]. According to the European Union, a third-country national (a person in a given state who is willing to move to another state, neither of which are their country of origin) or stateless person (outside his/her habitual state) is one who moves to other countries for the aforementioned reasons [52]. Similarly, an individual "seeking international protection from a country through individualized procedures, whose claim has not yet been finally decided by that country", is recognized as an asylum seeker by the UNHCR [49]. If such an application for protection was made under the Geneva Convention, then that individual is recognized as an asylum seeker in the EU [52]. Every recognized refugee is initially an asylum seeker [49].

In recent years, numerous resources have been dedicated to the search for factors that trigger migration. In general, the factors affecting a migrant's decisions are divided into "push" and "pull" factors: push factors are unfavorable attributes at the point of origin (where the migration begins), whereas pull factors are favorable attributes of the destination. Both of these factors can be economic, socio-political, or ecological [53]. Based on the decisions of migrants, migration is classified into two distinct groups: voluntary 
and forced [54,55]. Voluntary migration takes place "on a migrant's free will, initiative, and desire to live in a better place according to his/her aspiration" [53]. People can leave their country of origin for purely economic reasons to seek material improvements in their livelihood. Motivation can relate to the labor market, employment opportunities, or prospects of wealth. Such migration, pursued voluntarily for economic reasons, is termed as "economic migration" [51,52]. On the other hand, forced migration takes place when people flee (IDPs or refugees) as a result of a legitimate fear of persecution, or as a reaction to crisis situations arising from natural (e.g., environmental disaster, climate changes) or man-made causes (e.g., famine, war, conflict, violence) [52,53]. Voluntary migration is primarily driven by socio-economic factors, whereas refugees are forced to relocate for their own safety [56].

\subsection{Global Trends}

Human migration is a global phenomenon occurring since the dawn of human evolution, for reasons of safety, dignity, climate, and access to resources. According to the UNDESA, there are nearly 763 million IDPs worldwide [50]. The number of international migrants has reached an estimated 272 million, comprising $3.8 \%$ of the global population [50]. Labor migrants constitute nearly half of the total global number of international migrants. As mentioned, since 2010, a surge in armed conflict has led to increased levels of refugee flows. Nearly half of all international migrants reside in ten hotspots: the United States, which hosts $19 \%$ of the world's total, followed by Germany, Saudi Arabia, Russia, the United Arab Emirates, France, Canada, Australia, and Italy. In contrast, the most common countries of origin include India (18 million), Mexico (12 million), China (11 million), Russia (10 million), and Syria (8 million). The UNHCR has estimated that two-thirds of the world's refugees are produced from only five countries: Syria, Afghanistan, South Sudan, Myanmar and Somalia [1]. International migrants, whether moving voluntarily or involuntarily, have a degree of choice in their destination. Over $60 \%$ of international migrants choose neighboring countries or countries within the same region. Of the top ten bilateral migration corridors experiencing the largest annual increases, five are Syria to Jordan, Syria to Lebanon, Syria to Turkey, Palestine to Jordan, and Mexico to the United States [53]. The openness of these corridors is related to economic, social, and regional interests. With a high volume of migrants arriving in cities and refugee camps, governments and international organizations are challenged to provide adequate basic services (food, water, energy, employment, health, and education) [53]. The challenge in understanding the movement and flow of international migrants and the associated consequences on resources and the economy of the receiving and destination countries are current area of focus for the research communities around the world.

\subsection{Migration and Water}

The relationship between water and migration is often treated as a subset of environmental or climate change migration [57]. Water quality, scarcity, and exposure to extreme water events such as extreme rainfall, flood, or drought, can be major drivers for migration [58]. SDG target 6.4 is a development priority in the water sector of the UN 2030 Agenda, which addresses water scarcity and stress. Water stress can result from narrowly focused water management where resources are limited. For example, the extensive withdrawal of upstream freshwater from the Aral Sea directly contributed to the spread of waterborne diseases and loss of agriculture and fisheries, along with income, forcing local communities to migrate [59]. Mass human displacement attributed to extreme climate events, coupled with excessive withdrawal of water for agriculture, is also seen across regions. Lake Chad, a vital source for water and economic dependencies for communities in the Sahel region, shrunk by $90 \%$ due to continued drought and unmanaged irrigation, and triggered displacement, migration, and conflicts for control over diminishing water resources [49]. Water shortage and mismanagement has the potential to become a tool of conflict in the MENA region. The drought in Syria lasted from 2006 to 2011, resulted 
in mass population displacement, and is argued to be one of the major reasons spurring its ongoing civil war [60]. High migration flows can impose resource burdens on hosting countries. The water stress in one of these, Lebanon, has increased by $6 \%$ since it began hosting Syrian refugees [61]. In spite of the increased flow in the Yarmouk River, increasing fresh water demand by the refugees puts major stress on Jordan's water resources [62].

\subsection{Migration and Energy}

Energy, a prerequisite to social and economic development, and essential to poverty reduction, has hardly been discussed as a factor in migration [63]. The Council of the EU acknowledges the lack of uneven access to electricity to be part of the root cause of irregular migration, the primary development concern (SDG target 7.1) of the Agenda of the UN in the energy sector (EU Development Statement, 2016). The decision to migrate can depend on the connectedness between energy services and living standards. Energy poverty can lead to lack of agricultural processing, productivities, and economic opportunities [64]. Thus, energy can indirectly act as a 'push factor' for economic migration. Access to energy can increase food productivity, and improve management and access to water, thereby opening job opportunities and mitigating other push drivers such as food insecurity, poverty, and unemployment [64]. There is a significant positive linkage between global energy price and migration flow, especially in Middle Eastern countries where migration inflow increases with a rise in oil prices [65]. The driver of renewable energy can trigger forced migration: in Bangladesh, construction of the nation's only hydropower plant led to the dislocation of Indigenous people in the early 60's. Extraction of primary energy sources from densely populated areas can also lead to internal mass displacement [66]. In refugee camps, access to affordable energy is often inefficient, polluting, and poses adverse impacts to the surrounding environment compared to economic migration [67].

\subsection{Migration and Food}

Food security and migration are closely interlinked. The World Food Program (2017) reported that countries experiencing the highest level of food insecurity conjointly with armed conflict are main contributors to the volume of global refugees [46]. It has been seen that declining agricultural production can accelerate or amplify migration patterns [30]. Food is largely dependent on water and land availability, as environmental degradation can contribute to lower yield and loss of production. That is reflected in SDG target 2.4, which strongly considers resilient food production practices. Food insecurity resulting from extreme drought has been one of the major causes for migration from Mexico to the USA [47]. Food insecurity is an even stronger driver than conflict-induced migrations, and causes almost $2 \%$ more people per 1000 to migrate with each one percentage raise [46]. As seen in the MENA region, increasing population and inefficient management of land and water, coupled with unfavorable climate, contributes to increased food insecurity [68]. The loss of income due to exposed domestic food, coupled with recurring drought and conflict, have recently increased the international migration flow from the Central American nations [69]. The impact of food security on host cities and countries is critical, especially when hosts have a pre-existing food deficit. Prevalence of severe food insecurity and malnutrition in Jordan, Lebanon, Liberia, Chad, and Niger are directly interlinked with hosting refugees [70]. Food accessibility is mainly dependent on food prices and household resources [71]. Without food assistance from international organizations, such large migration inflows alter the stability of existing agricultural markets, raising demand and prices whilst lowering the purchasing power of both the host and the refugee communities [70]. Food insecurity, conflict, and migration operate in a vicious cycle: conflict disrupts food production and markets, and can result from food scarcity itself. In both cases, migration can be either forced or voluntary [46]. Figure 1 summarizes the discussed interconnections among water, energy, food, and migration. 


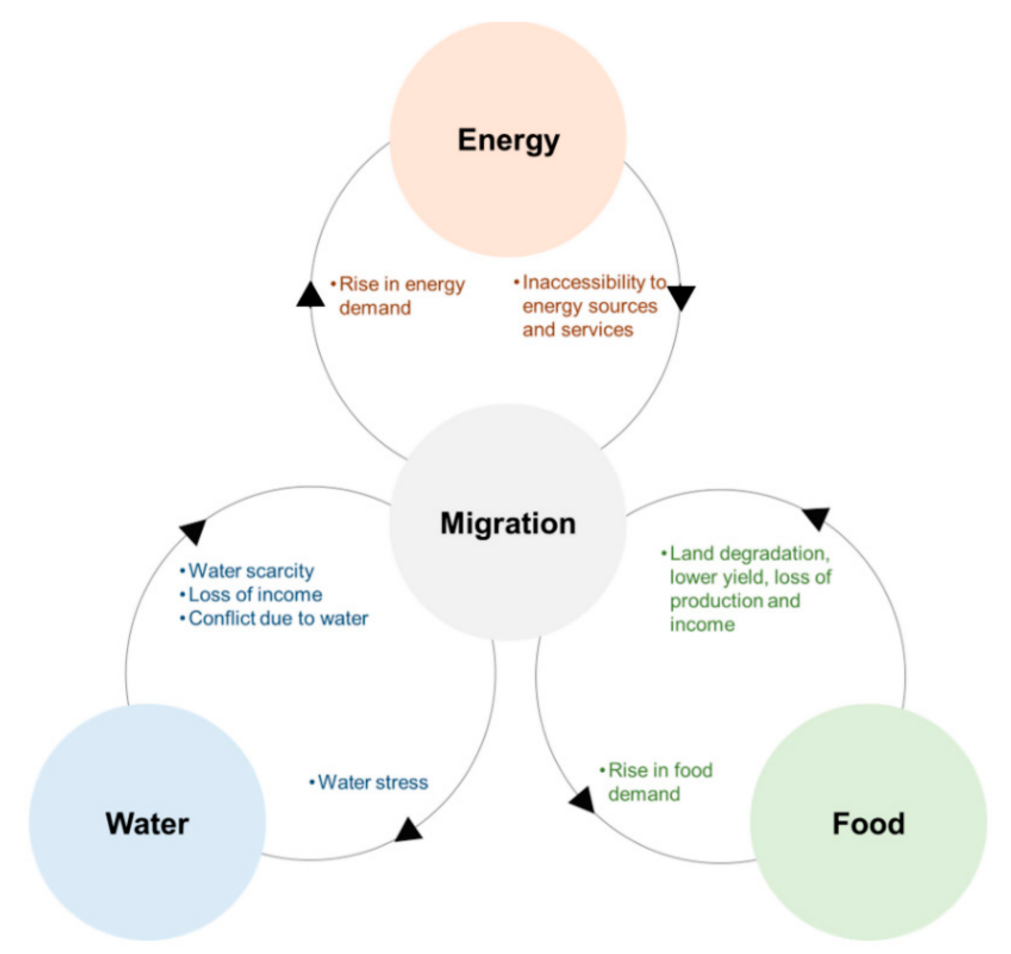

Figure 1. Interconnections between water, energy, food, and migration.

\subsection{Migration Models}

Migration is a complex process that involves certain human mobilities, historical factors, and the individual decisions of migrants. To model and forecast or investigate migratory movement, a notable number of modelling theories and tools have been developed. Ravenstein (1885) first theorized that international migration paved the way for using gravitational laws to model migration patterns between two places, origin and destination, based on different socio-economic push and pull factors [72-75]. The range of implementing gravity models covers voluntary to forced migration. Notable limitations to this model include the lack of theoretical guidance on a number of parameters to be considered (push and pull factors, power law, and exponentials) and the inability to capture any sudden fluctuation in numbers between locations of origin and destination [76]. An improved version of the gravity model is the radiation model, which is parameter-free and can be gradually upscaled using a statistical mechanics approach [57]. However, this model cannot capture the migration pattern resulting from an abrupt shock, such as population movement due to the sudden emergence of a natural disaster. Both models mentioned can display mass movement resulting from evacuation. Institutional tools, such as the UNHCR demographic projection tool, focus more on defining future size and composition of a forcibly displaced population, and exclude the cause of migration [77]. Rabinson and Dilkina (2017) have also introduced a machine learning approach for projecting general migration patterns [78].

Extensive research has been done on human movement modelling in different temporal and spatial scales to overcome the limitations found in gravity and radiation models. As migration modelling can cover space from small distances to half of the world, its temporal scale can vary from as short as hours to years; Groen (2016) identified three different ways of modelling human movement: evacuation modelling, refugee modelling, and migration modelling [79]. Evacuation modelling is widely used in crowd movement and urban evacuation [80]. Chen and colleagues (2018) used an agent-based modelling approach to test hypotheses in economic migration from Mexico to the USA and identify key behavioral motives behind migration [81]. Lin and colleagues (2016) used a country level agent-based dynamic network model to examine population displacement based on networks among countries, an example of voluntary migration [82]. Agent-based mod- 
els (ABM) are also used in disaster-driven forced migration in Bangladesh [83] and in predicting refugee destinations due to forced migration in Africa. The ABM approach has also been used by Sokolowski and Banks (2014) and Herbert and colleagues (2018) to model refugee allocations in Syria in different cities inside and outside the country [84]. While ABM is becoming popular in simulation-based approaches, the accuracy of the model depends on the detail of the design and specific data for modelling a heterogenous mixture of interacting behaviors at higher levels [85]. Conflict-induced forced migration modelling using an Agent Based Framework (CoFMMA) is a simulation-based method that employs aspects of localized decision making to produce emergent large-scale movement patterns [86]. Most recently developed models are more focused on agent-based-modelling, as it captures the behavioral aspect of migrants. Theories of decision making are diverse and the success of the model depends on the effective capture of interacting behaviors [87]. On the other hand, predictive models that combine data on migration drivers or decisions are limited in the field of forced migration [88]. In spite of availability of different methods, the key question lies on the robustness of models in projecting migration flows for different temporal and spatial scales.

The ABM method essentially captures the individual behavior of migrants. For a large number of migrants, the model uses probabilistic or statistical data for simulation, which may not be representative of migration flows. Although multiple sources of data on global migration are available (UNHCR database, migration data portal, International Migration Statistics, country specific databases, and IOM's one-stop-shop for international data), ABM modelling specifically requires data that reflect emerging behavior due to a sudden shock. Perhaps one of the most lauded approaches to foresight migration is scenario building to inform decision makers regarding how the flow of migration might change under different scenarios [88]. Table 1 lists these discussed migration models in respect of the types, scale, analytical tool, and context.

Table 1. Types of migration models.

\begin{tabular}{|c|c|c|c|c|c|c|}
\hline Model & Migration & Author & Scale & Tool & Context & Remarks \\
\hline \multirow{4}{*}{ Gravity Model } & Voluntary & Mayda, 2010 & International & $\begin{array}{l}\text { Statistical } \\
\text { Analysis }\end{array}$ & $\begin{array}{l}\text { Economic and } \\
\text { non-economic } \\
\text { determinants of } \\
\text { migration to OCED } \\
\text { countries }\end{array}$ & $\begin{array}{l}\text { Utilizes open } \\
\text { source data }\end{array}$ \\
\hline & Voluntary & Poot et al., 2016 & $\begin{array}{l}\text { Internal and } \\
\text { International }\end{array}$ & $\begin{array}{l}\text { Statistical } \\
\text { Analysis }\end{array}$ & $\begin{array}{l}\text { Migration pattern based } \\
\text { on mobility between } \\
\text { sources and destinations. }\end{array}$ & $\begin{array}{l}\text { Data intensive } \\
\text { Focused on } \\
\text { general pattern } \\
\text { of migration }\end{array}$ \\
\hline & Voluntary & $\begin{array}{l}\text { Dharmadasa } \\
\text { and Herath, } \\
2018\end{array}$ & International & $\begin{array}{l}\text { Statistical } \\
\text { Analysis }\end{array}$ & $\begin{array}{l}\text { Economic migration } \\
\text { based on economic } \\
\text { determinants from } \\
\text { Srilanka to Middle East } \\
\text { countries }\end{array}$ & $\begin{array}{l}\text { Identifies push } \\
\text { and pull factors } \\
\text { of economic } \\
\text { migration }\end{array}$ \\
\hline & Forced & $\begin{array}{c}\text { Saldarriga and } \\
\text { Hua, } 2019\end{array}$ & Internal & $\begin{array}{l}\text { Statistical } \\
\text { Analysis }\end{array}$ & $\begin{array}{c}\text { Influence of social } \\
\text { network on the choice of } \\
\text { victims of forced } \\
\text { migration due to } \\
\text { violence in Colombia }\end{array}$ & $\begin{array}{c}\text { Requires access } \\
\text { to city specific } \\
\text { data and } \\
\text { national } \\
\text { database }\end{array}$ \\
\hline
\end{tabular}


Table 1. Cont.

\begin{tabular}{|c|c|c|c|c|c|c|}
\hline Model & Migration & Author & Scale & Tool & Context & Remarks \\
\hline \multirow{2}{*}{$\begin{array}{l}\text { Radiation } \\
\text { Model }\end{array}$} & Voluntary & $\begin{array}{c}\text { Simini et al., } \\
2012\end{array}$ & Internal & $\begin{array}{l}\text { Statistical } \\
\text { Analysis }\end{array}$ & $\begin{array}{l}\text { Focused on human } \\
\text { mobility based on modes } \\
\text { of communication }\end{array}$ & $\begin{array}{c}\text { Emphasis on } \\
\text { general } \\
\text { migration } \\
\text { pattern; } \\
\text { Requires data } \\
\text { which might be } \\
\text { hard to access. }\end{array}$ \\
\hline & Forced & $\begin{array}{c}\text { Davis et al., } \\
2018\end{array}$ & Internal & $\begin{array}{l}\text { Statistical } \\
\text { Analysis }\end{array}$ & $\begin{array}{c}\text { Projection of climate } \\
\text { driven migration in } \\
\text { Bangladesh due to sea } \\
\text { level rise }\end{array}$ & $\begin{array}{l}\text { Utilizes open } \\
\text { source data } \\
\text { Connected } \\
\text { migration flow } \\
\text { with excess } \\
\text { demand of } \\
\text { food, jobs and } \\
\text { housing }\end{array}$ \\
\hline \multirow{5}{*}{$\begin{array}{l}\text { Agent Based } \\
\text { Model }\end{array}$} & Voluntary & $\begin{array}{c}\text { Chen et al., } \\
2018\end{array}$ & International & $\begin{array}{c}\text { Statistical } \\
\text { Analysis }\end{array}$ & $\begin{array}{c}\text { Key behavioral motives } \\
\text { of migrants from Mexico } \\
\text { to USA }\end{array}$ & $\begin{array}{l}\text { Data collected } \\
\text { from interviews } \\
\text { of individual }\end{array}$ \\
\hline & Forced & $\begin{array}{l}\text { Suleimenova } \\
\text { et al., } 2017\end{array}$ & International & $\begin{array}{c}\text { FLEE } \\
\text { Simulation } \\
\text { Framework }\end{array}$ & $\begin{array}{l}\text { Predicting flow of } \\
\text { refugees in refugee } \\
\text { camps due to conflicts in } \\
\text { African countries }\end{array}$ & $\begin{array}{c}\text { Suitable to } \\
\text { predict refugee } \\
\text { volume across } \\
\text { camps during } \\
\text { conflicts }\end{array}$ \\
\hline & Forced & $\begin{array}{l}\text { Herbert et al., } \\
\quad 2018\end{array}$ & International & Simulation & $\begin{array}{l}\text { Refugee mobility and } \\
\text { flow prediction from } \\
\text { Syria to neighboring } \\
\text { countries based on } \\
\text { incident of violence }\end{array}$ & $\begin{array}{l}\text { Only considers } \\
\text { death toll as a } \\
\text { variable directly } \\
\text { related to } \\
\text { violence }\end{array}$ \\
\hline & Forced & De Kock, 2019 & International & $\begin{array}{c}\text { CoFMMA } \\
\text { Framework }\end{array}$ & $\begin{array}{l}\text { Predicting flow and } \\
\text { direction of refugees } \\
\text { during conflicts from } \\
\text { Syria to Jordan }\end{array}$ & $\begin{array}{l}\text { Data intensive } \\
\text { High } \\
\text { complexity }\end{array}$ \\
\hline & Forced & $\begin{array}{c}\text { Hussani- } \\
\text { Mahmooei and } \\
\text { Parris, } 2012\end{array}$ & Internal & Simulation & $\begin{array}{l}\text { Predicting flow of IDPs } \\
\text { from different part of } \\
\text { Bangladesh due to } \\
\text { climate change }\end{array}$ & $\begin{array}{l}\text { Utilizes open } \\
\text { source data } \\
\text { Long term } \\
\text { projections }\end{array}$ \\
\hline
\end{tabular}

\subsection{Research Gaps}

Existing migration models are human mobility models focused on capturing the size or flow of the migrants, whether due to voluntary (economic) or involuntary (conflict, environmental or climate change) reasons $[72-75,86]$. Gravity and radiation models are crafted functional forms, connected to a few factors, and identified in origin and destination, respectively [78]. Agent-based models are mostly used in predicting human movement attributed to forced migrations $[83,84,89]$. Although the developed models, from a statistical to a simulation approach, have distinct techniques that capture migration flows, there are hardly any models that capture the tight interaction of water, energy, and food together with migration, either in one-to-one or an integrated manner. The World Food Program (2017) estimated that food insecurity forced five times more people to migrate than conflict-induced migration [46]. Food security is also strongly connected with water and energy security [18]. Models connecting water, energy, and food with migration can bridge the gap to understanding the salient migration pattern, either voluntary or forced, when migration is a critical issue to address. 


\section{Pandemics, Infectious Disease, and the WEF Nexus}

Pandemics are defined as "epidemics of infectious or contagious disease that have spread through populations across a large region, crossing international boundaries" [90]. Historically, pandemics have been caused by bacterial and viral diseases such as cholera, influenza, smallpox, plague, malaria, and a host of hemorrhagic fevers (e.g., Ebola) [90]. While pandemics are relatively rare, they can wreak havoc on populations, decimate economies, and significantly disrupt supply chains, which can subsequently shock the WEF nexus. The most devastating pandemic in recent history, the 1918 Influenza pandemic, caused approximately 50 million deaths worldwide [91]. The 1918 pandemic consisted of three waves in which the world witnessed resurgences of the virus lasting until the summer of 1919 [91]. During this time, the per capita gross domestic product (GDP) shrank an average of $6 \%$ [92]. One hundred and two years later, the COVID-19 pandemic has caused over five hundred thousand deaths in the United States alone [93]. In order to slow the spread of the virus, the economy has essentially shut down and unemployment rates have increased to $14.7 \%$ [94].

\subsection{Pandemics, Infectious Disease, and Water}

In developed countries such as the United States, the likelihood of an infectious disease spreading through treated drinking water is low. In developing countries with lower capacity to treat drinking water, infectious diseases such as Salmonella, Norovirus, Cryptosporidium, cholera, dysentery, polio, and E. coli can spread through water systems $[95,96]$. One way that water can become contaminated, particularly in water-scarce countries, is when strategies are implemented to re-use wastewater without proper safety measures; another challenge is that, in severely water-scarce countries, hand washing may be perceived as wasteful, thereby increasing the likelihood of infectious diseases [96]. Diseases not spread directly through water can still severely impact water systems in both developed and developing countries. According to the National Rural Water Association [97], a pandemic such as COVID-19 could "cause serious disruptions to the operations of drinking water systems" through "staffing shortages, power disruptions, and shortages of chemicals and other supplies" (p. 5). Le Blanc (2015) cited the interlinkage among SDG target 6.1 (access to safe water), 6.2 (access to safe water for hygiene), and the communicable diseases (SDG target 3.4), which implies an interconnected public health issue to be addressed [11].

\subsection{Pandemics, Infectious Disease, and Energy}

Pandemics and infectious disease can have massive impacts on the energy sector. During the COVID-19 pandemic, millions of individuals around the world began working from home. This led to a sharp decrease in the use of public and private transportation. The International Energy Agency (2020) reported that "road transport in regions with lockdowns in place dropped between $50 \%$ and $75 \%$, with global average road transport activity almost falling to 50\% of the 2019 level" [98]. Aviation travel had reduced by $60 \%$ by the end of Quarter 1 in 2020. Lockdowns have also led to a $20 \%$ decrease in demand for electricity. As the COVID-19 pandemic continues, energy usage is expected to remain low [98].

\subsection{Pandemics, Infectious Disease, and Food}

It is important to note that infectious diseases in animals and plants can pose serious threats to interconnected resource systems. Ireland's Great Famine of 1845, caused by the pathogenic fungus Phytophthora infestans in potatoes [99], resulted in Ireland's loss of nearly all of its potato crop, among other crops, resulting in a famine that claimed nearly 1.5 million Irish lives and caused the emigration of another 1.5 million. Outbreaks of disease in crops and livestock result in loss of production and expose the resilience of domestic agriculture, which adversely impact SDG targets 2.2 (malnutrition), 2.3 (productivity), and 2.4 (capacity of production). Even when not directly spread through animals or plants, infectious disease can still shock the agri-food industry. During the months of March and 
April 2020, farmers across the United States had to dump thousands of dollars of extra produce in their fields [100]. The lockdowns and fears of entering public spaces led to decreased demand for vegetables, fruit, eggs, and milk from grocery stores around the country. With restaurants closed, farmers simply had to throw out the extra. The meat industry also saw incredible loss as meat packing facilities around the country closed for the safety of their workers [101]. Thus, pandemics can hurt small-scale food producers and farmers (SDG target 2.4), and can disrupt food price volatility due to shock in demand (SDG target 2.3). The losses to the agriculture, pork, and cattle industries in the U.S. were expected to surpass $\$ 1$ billion, $\$ 700$ million, and $\$ 5$ billion, respectively [100,101]. Figure 2 depicts the identified interactions between water, energy, food, and pandemics.

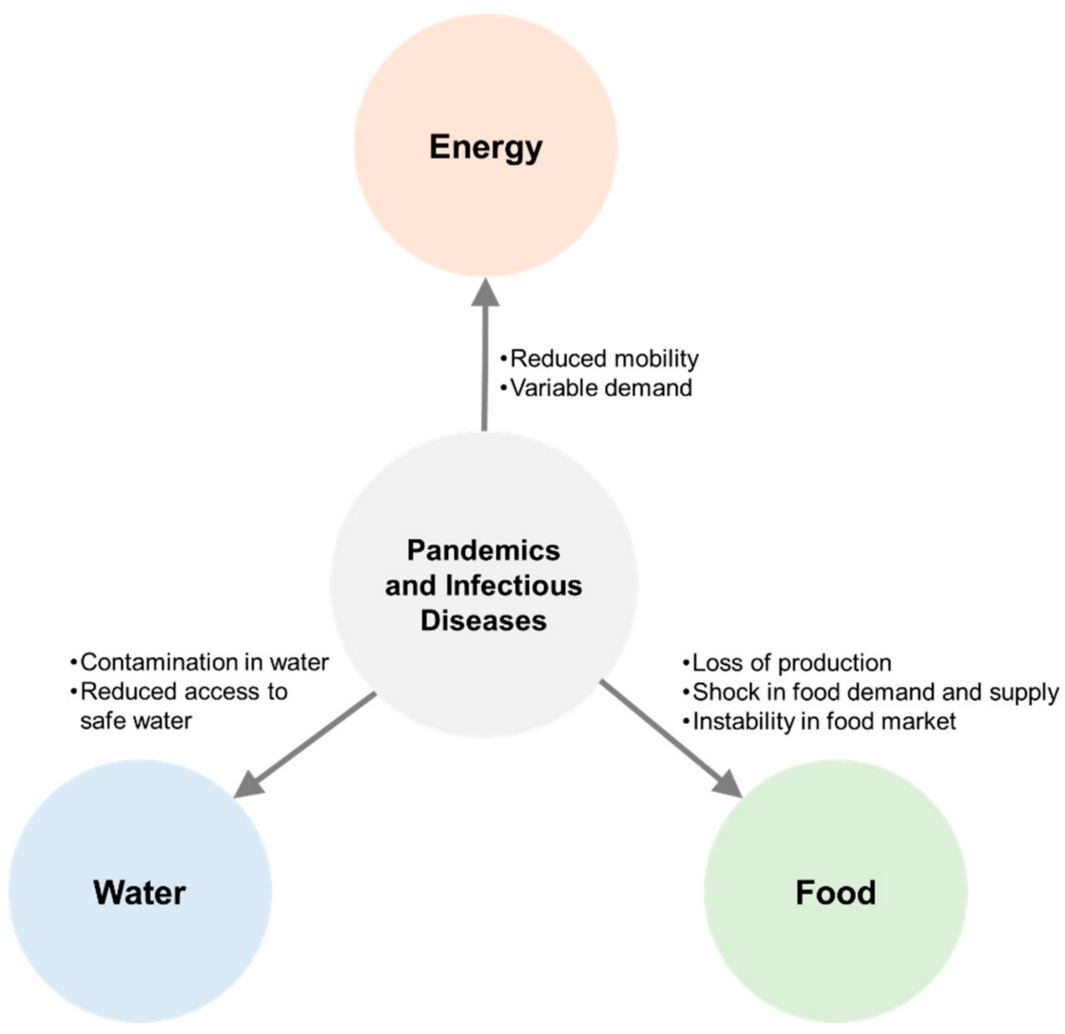

Figure 2. Interactions among water, energy, food, and pandemics.

\subsection{Existing Models and Research Gaps}

Extensive research work has been done on the transmission and propagation of infectious human diseases based on the SIR (Susceptible-Infective-Recover) model [102]. Modelling epidemics of plants, as well as actual yield loss, adopt modified structures having similar concepts of disease propagation [103,104]. The spread of COVID-19, coupled with plant epidemics, can severely affect crop yields, disrupt the food supply chain, and increase hunger related fatality [105]. Huff et al. (2015) developed a simulation model to predict the resilience of the food system supply chain based on labor availability in response to pandemics [106]. The model predicts the impact on the food system based on the relationship between pandemics, workforce, and water and energy systems necessary for food and agricultural processes. Such a model could be a good foundation to further understand and capture critical interconnections between integrated food, energy, and water security, crop epidemics, and pandemics using a common framework.

\section{Natural Disasters and the WEF Nexus}

Natural disasters can include events such as earthquakes, extreme heat, floods, hurricanes, landslides, mudslides, lightning, tornadoes, tsunamis, volcanic eruptions, wildfires, and severe winter weather [107]. They can pose a grave threat to human life, critical 
infrastructure, and homeland security [108]. Globally, disaster management and resilience programs are more focused on post-disaster strategies in which the nature and magnitude of impacts on water, energy, and food resource systems remain understudied. While international organizations are looking into resource (food and water) specific resilience planning, the vulnerability arising from cross sectoral interaction among water, energy, and food should be probed to bridge the gap and realize the true magnitude of disaster impact.

\subsection{Natural Disasters and Water}

Natural disasters directly or indirectly affect the quality and quantity of water resources. Floods and cyclones can degrade water quality through contamination, which in turn, can affect water availability and impact public health. Long-term drought can reduce water availability [44]. As water has tight interconnections with food production and energy, the degradation of usable water resources due to the frequent occurrence of natural disasters can directly impact food and energy security. In 2005, Hurricane Katrina severely disrupted the supply chain for water and food, causing staggering damage that totaled $\$ 108$ billion [109]. Ensuring safe water for drinking (SDG target 6.1) and hygiene (SDG target 6.2) is a top priority in post-disaster rehabilitation activities. Areas frequently affected by flood, cyclones, or drought also suffer in loss of food production [44,110].

\subsection{Natural Disasters and Energy}

The direct relationship between natural disasters and energy can be traced to the physical damage of energy sources and availability. Tornados, earthquakes, landslides, and other disasters can cause damage to or entirely destroy electricity grids and physically damage power plants, thereby disconnecting the supply of energy in the affected area [108]. Such disruption to energy access can directly affect water accessibility and food production.

\subsection{Natural Disasters and Food}

Natural disasters, particularly those involving water (e.g., hurricanes, floods, droughts), are often exacerbated by rapid urbanization and poor ecosystem management [111]. Waterrelated natural disasters have the potential to cause widespread damage to a nation's critical infrastructure, including its agriculture industry. Floods, landslides, and storms are capable of destroying essential crops, which can subsequently lead to hunger or starvation [111]. In developing countries, the agriculture sector absorbed about $22 \%$ of the total damages and losses caused by natural disasters from 2003 to 2013 [44]. More than $80 \%$ of the damage and losses caused by drought has affected agriculture. Sub-Saharan countries lose a value-added growth in agriculture up to 3.5\% after each drought [84]. Water-related natural disasters have the potential to cause widespread damage to a nation's critical infrastructure, including its agriculture industry. In 1991, approximately three MMT of cereal and food crops were totally destroyed by a cyclone in Bangladesh [112]. Most of the food production losses occur after the disaster and account for $83 \%$ of total losses [44]. When the crop and food production centers are affected by natural disasters, the impact spreads to surrounding regions, leading to malnutrition, hunger, and a rise in food prices. About 85,000 hectares of crops were burnt due to field fires in Syria in 2019 [113]. The long drought (2006-2011) event collapsed agricultural yields and drove 1.3 million Syrians from rural areas into cities [114]. Thus, shocks induced or caused by natural disasters significantly affect productivity (SDG target 2.3), production capacity (SDG target 2.4), and accessibility to adequate food (SDG target 2.1) in disaster prone areas. Figure 3 illustrates the interconnections between water, energy, food, and natural disasters. 


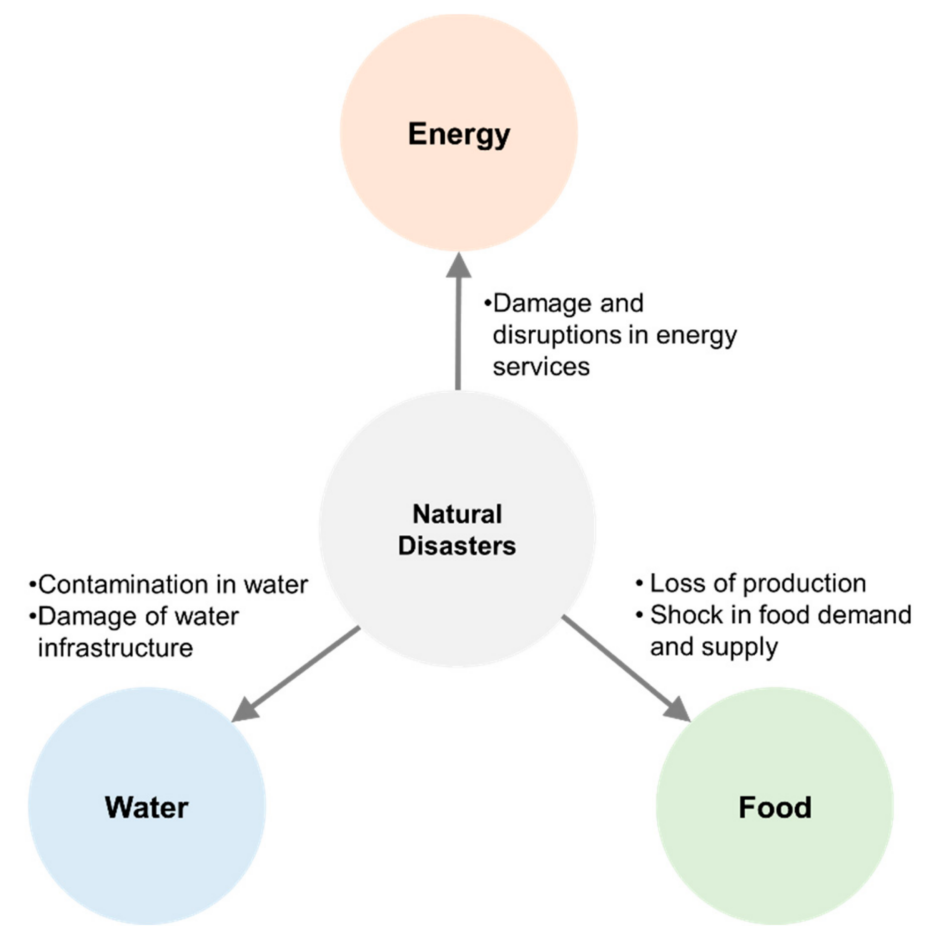

Figure 3. Interconnection among water, energy, food, and natural disaster.

\subsection{Existing Models and Research Gaps}

In spite of significant impacts of natural disaster on food supply chain, production, water, and energy infrastructures, most of the models available for post disaster impact analysis are economic, concentrating on quantification of direct and indirect loss (I/O models, CGE models, demand and supply driven models) and shock responses in supply chains $[115,116]$. Israel and Briones (2012) quantitatively analyzed the impact on agriculture, food security, and natural resources from the severity and type of natural disaster based on past data from the Philippines [117]. Most of the frameworks and studies were found to be more concerned with post disaster food and health securities than integrated security of water, energy, and food, or human displacement [118].

\section{Interconnections between Migration, Pandemics, and Natural Disasters 6.1. Migration and Pandemics}

Infectious disease and human migration arguably affect each other in a reciprocal manner. Infectious diseases are spread by the movements and interactions of people. Likewise, people may be motivated to change locations in order to escape a growing endemic. Throughout the COVID-19 pandemic, for instance, refugees have tried to move onward from Greece following the lack of protection from the disease, which has put thousands in the Moria refugee camp at risk [119]. These movements, motivated by or resulting from infectious disease, not only place pressure on basic resources in the receiving locations, but also potentially compromise the health of those in the receiving locations [120-122]. As discussed, forced migration can occur as a result of armed conflict. Unfortunately, infectious diseases often thrive in regions fraught with conflict and can be transferred from the region of conflict to new areas by migrants. Not only are physical health care resources (hospitals, equipment, technology) destroyed as a result of conflict, but doctors and trained healthcare workers seek refuge elsewhere [120,123], leaving the region of conflict strained or entirely unable to provide critical services such as vaccination programs. The "clustering of mass numbers" of migrants in refugee camps, often without health care, poses further risk for the spread of infectious disease. According to Blackburn and Lenze (2017), this "creates the perfect breeding ground for diseases like yellow fever, cholera, tuberculosis, and Ebola. Refugee camps serve as a particularly good place for cholera outbreaks, due to 
the lack of adequate waste disposal" [120] (p. 3). In Greece, officials shut down the Moria refugee camp in an effort to contain the Coronavirus; however, cramped conditions placed 20,000 refugees at risk for contracting and spreading the disease [119]. This introduces an ethical dilemma in which countries seek to protect their own citizens from disease outbreaks while leaving refugees in "more dangerous pandemic incubators than cruise ships" [124].

The spread of infectious disease as a result of conflict is not a new phenomenon. The 1918 influenza pandemic was exacerbated by the conflict of World War I. The international travel of soldiers was a contributing factor that facilitated the spread of the virus [92]. Conflict within Tajikistan in 1992 created forced migration flows into neighboring Afghanistan [123]. Although malaria had been eradicated in Tajikistan for 35 years, the nearly 100,000 refugees who had settled in Afghanistan reintroduced malaria upon their return to Tajikistan in 1994. According to Gayer et al. (2007), this led to an outbreak and the subsequent reestablishment of malaria in Tajikistan [123]. Today, conflict in the Middle East has led to severe outbreaks of infectious diseases, some having previously been eradicated, as in the Tajikistan case. Polio reemerged in Syria in 2013 and, by 2016, Europe experienced polio outbreaks due to the large number of Syrian refugees in the region $[120,125]$. Cases of tuberculosis and cutaneous leishmaniasis, brought from Syria, have increased in Lebanon [126]. Containment measures made by developing countries in the midst of a pandemic fail to protect vulnerable groups of migrant laborers when governments are unexpectedly shut down. For example, India's nationwide lockdown in the midst of the COVID-19 pandemic has left countless migrant workers among the population of 1.3 billion people unemployed and unprotected from the novel virus [127]. Migrant workers were forced to return, on foot, to their native rural towns from the large cities of employment following the Indian government's shut down of public transportation to prevent the spread of the virus. According to the Maharashtra Medical Education and Drugs Department Reports, "States home to large numbers of returning migrants have seen a sharper percentage rise in cases" from April to May 2020 in rural areas. In the eastern state of Bihar, the same medical reports also showed that "... of the 3872 coronavirus cases recorded until the 1st of June, 2743 cases were linked to migrant workers who returned to their native towns and villages after May 3rd, when the government began to run trains and buses again to reduce the exodus on foot" [128].

The connection between forced migration and infectious disease seems to affect and be affected by the interconnected resource systems in host countries [121]. For example, a lack of access to clean water can facilitate the spread of disease. The UNHCR (2000) outlines the requirements to maintain hygiene standards within refugee camps, including such things as clean-water sources, pumps, taps, vessels for the transfer and storage of water, and sanitation systems $[90,129]$. In host countries where water resources are scarce, it can be difficult to provide these things: water is essential to a robust agriculture industry. Host countries with few water resources might also struggle to provide a sufficient food supply for refugees, which, in turn, can exacerbate infectious disease: if refugee populations become malnourished, the host country's public health becomes at risk to communicable and vector borne diseases, a thematic issue in health-related SDG target 3.3 and safe migration (SDG target 10.7).

\subsection{Migration and Natural Disasters}

Along with pandemics and infectious disease, natural disasters are another reason for individuals to migrate, as natural disasters can have an immense impact on WEF resources. Take, for example, Hurricane Harvey, a Category 4 hurricane that hit the coast of Texas and Louisiana in the fall of 2017. Not only did warnings of the hurricane cause many people to flee to neighboring cities and states, placing pressures on the water, energy, and food chains in those areas, but the hurricane itself destroyed 156,000 homes, caused 39 deaths, and destroyed or significantly interfered with WEF resources in Houston [130]. Because of the intense flooding, many individuals were trapped in their homes and struggled with 
complications accompanying home damage and water contamination [130,131]. Sea level rise can displace the people living in coastal and small island locations: for example, sea level rise in Bangladesh could result in the movement of 1 million internally displaced persons [57].

\subsection{Pandemics and Natural Disasters}

According to Watson at al. (2007), outbreaks of disease following a natural disaster can be attributed to population displacement [132]. As stated, natural disasters can destroy critical infrastructure, including healthcare resources and water treatment facilities. In general, disease outbreaks after floods are more common than after disasters such as earthquakes or volcanic eruptions, due mainly to contact with contaminated water. For example, after the 2004 flooding in Bangladesh, over 17,000 individuals contracted diarrhea from contaminated drinking water. Water-based natural disasters can increase the risk of infectious disease, as many vectors breed in water. Flooding and hurricanes can leave behind large areas of standing water where disease-carrying insects (e.g., mosquitos carrying malaria) can breed, affecting the general health of the population (and affecting SDG target 3.3) in addition to food scarcity [132]. Natural disasters often force large groups of individuals to be crowded together as they seek refuge in environments that also foster the spread of infectious disease. After Mt. Pinatubo erupted in the Philippines in 1991, approximately 18,000 individuals contracted measles while living together in close quarters [132].

\subsection{COVID-19, Natural Disasters, and Migrants: An Example of Compounded Shocks}

On top of the global pandemic, Bangladesh faced the first seasonal tropical cyclone 'Amphan', a category 3 hurricane from the southern coastal area on 15 May 2020, followed by the monsoon flood from the northern part of the country on 29 June 2020 [133,134]. Amid a countrywide lockdown, 'Amphan' and the monsoon flood have come as triple disasters to farmers already struggling to deal with the fallout of market supply and demand and the catastrophic damage caused by the cyclone. For nearly 10 million people in the southern part of Bangladesh, cyclone 'Amphan' caused damages worth 11 billion BDT in 26 districts, damaging infrastructures, and flooding arable lands and sources of drinking water $[135,136]$. During mass evacuation, nearly 2.2 million people were moved to 12,000 shelters with the added risk of compromised health in the face of the spread of Covid-19 [137]. According to the Ministry of Agriculture of Bangladesh, nearly 0.17 million hectares of agricultural land was battered and flooded due to the cyclone, affecting almost $20 \%$ of total agricultural land in the region [138]. The refugee camp in Cox's Bazar of Bangladesh, hosting nearly three quarters of a million Rohingya people, is more vulnerable to the impact of the pandemic than to the cyclone. With a scarcity of space, heavy rainfall has weakened the fragile shelter infrastructure in refugee camps, increasing the already high fear of landslides and flood [139]. The monsoon has already flooded 27,000 thousand hectares of land prepared for grains, vegetables, and cash crops [134]. Being confronted by a cyclone, flood, and pandemics, the overall impacts are yet to be assessed but will encompass food and water security as well as human displacement in coming years.

\section{Framework for Integrating Shocks in WEF Nexus Assessments}

In the last few decades, migration events, natural disasters, and the spread of diseases have been growing in frequency $[140,141]$; however, interconnections among migration, natural disasters, and pandemics are yet to be explored and properly quantified. Globally, migration decisions are becoming more connected to the extent of access to basic resources, including water, energy, and food. Similarly, natural disasters and pandemics have direct and indirect, long- and short-term impacts on water, energy, and food systems. Communities closely dependent on basic resources become the most vulnerable when facing resource scarcity and loss of livelihood due to adverse impacts imparted by natural disasters or pandemics, as well as conflicts and decisions to move as an adaptive strategy. Based on the events cited in previous sections, both natural disasters and pandemics can impose serious 
shocks in water, energy, and food systems, where the cross-sectoral effects can propagate due to intrinsic and extrinsic resource interactions. Moreover, the host communities have to be prepared by realizing their resource capacities and such externalities as migrants begin to settle. Migration, natural disasters, and pandemics are connected either directly or indirectly to the provision of basic resources, water, energy, and food. There is a need for expanding existing models and their ability to capture the outlined individual and compound shocks. These phenomena will have different impacts and will create varying levels of urgency in different regions. This will depend on factors including the availability of disaster response plans, integrative planning across different agencies, local human and institutional capacities, and technological availability, among others. Such factors need to be considered when evaluating the preparedness to respond to possible scenarios of compound shocks and their implications on resource security. Figure 4 summarizes the cited and observed interconnections outlined in this paper.

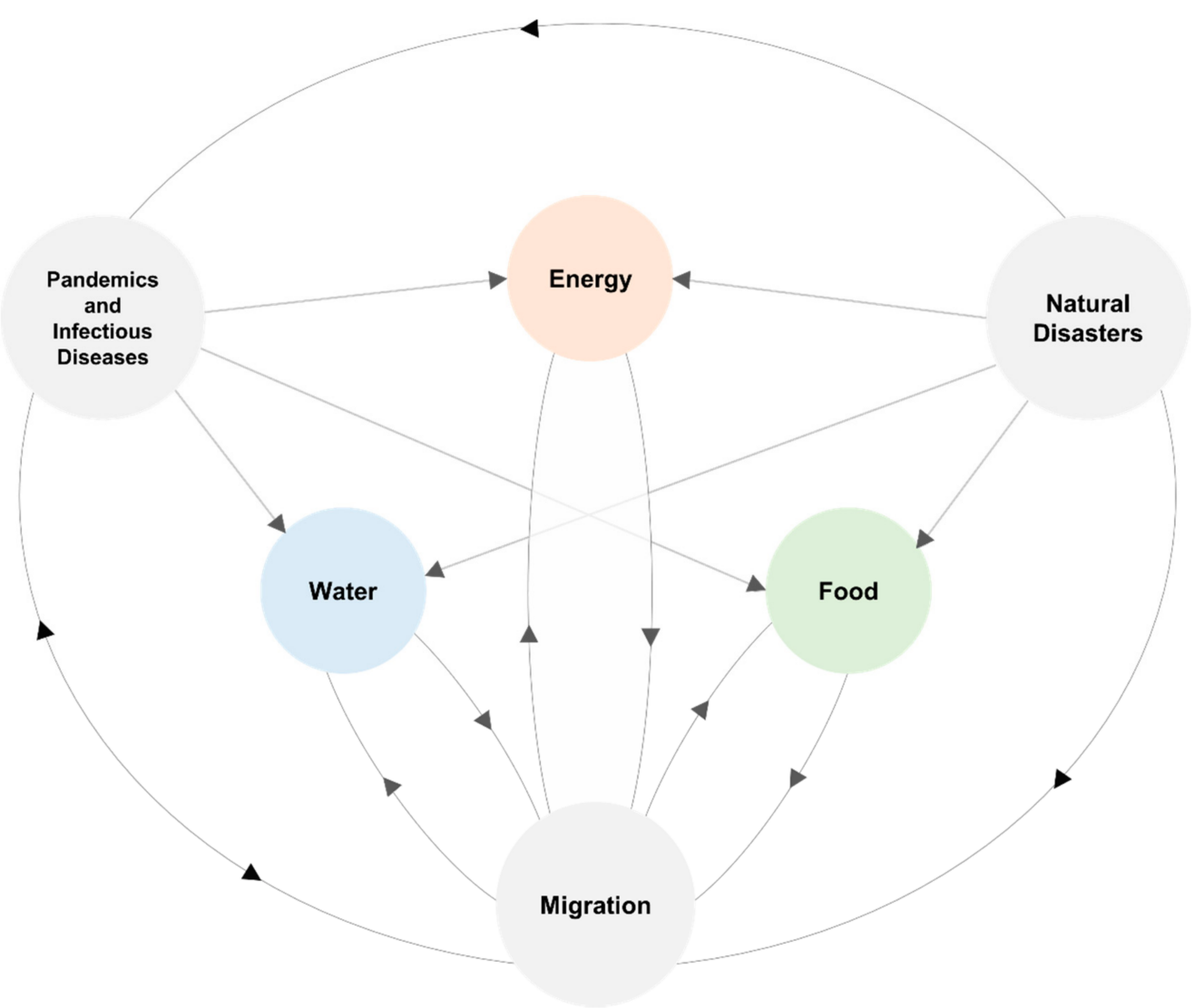

Figure 4. Shocks to WEF interactions from migration, natural disasters and pandemics.

\section{Conclusions}

In this paper, the authors highlight the existing literature surrounding the WEF nexus and identify critical pressures influencing it, particularly those of migration, pandemics and infectious diseases, and natural disasters. Understanding the interconnections between water, energy, and food, in light of pressures from migration, pandemics, and natural disasters (which are further exacerbated by factors such as climate change), is crucial to achieve the SDGs outlined in the 2030 Agenda for Sustainable Development. The present and immense challenges to interdependent resources alongside future unforeseen circumstances will continue to lengthen the gap between the world's meeting of the sustainable development goals. From reviewing the literature, we find examples demonstrating the relation between a lack of water and food security and people being forced to change their residence, temporarily or permanently (e.g., the drought in Mexico caused migration to the U.S.). Migratory flows have caused water and food scarcity (e.g., Lebanon and Jordan). 
Natural disasters and climate change also served as the base for intra-state migration (e.g., Bangladesh; Hurricane Katrina). The mismanagement of water and food systems in Central America were found to be leading drivers of migration as farmers' markets worsened [142]. Thus, resource stresses can trigger migration or be triggered by migration, leading to the causation or worsening of associated events (pandemics and disease spread). Multi-sectoral decision makers lack the tools for quantifying the impact of anticipated migration flows, natural disasters, and pandemics on these interconnected resource systems and on economic, social, and environmental indicators. Such tools could play a key role in the development of effective policies and management strategies across sectors to minimize any anticipated pressures. This would require a convergent approach, bringing different disciplinary experts to co-create multifaceted solutions that respond to their social, economic, technological, and policy dimensions of this grand challenge.

Author Contributions: Conceptualization, S.H. and K.P.; Methodology, B.D., S.H. and K.P.; Supervision, B.D., S.H. and K.P.; Writing-original draft, B.D., M.N.K. and T.T.; Writing-review \& editing, B.D., S.H. and K.P. All authors have read and agreed to the published version of the manuscript.

Funding: This research was funded by the Texas A\&M Energy Institute Seed Funding Program.

Institutional Review Board Statement: Not applicable.

Informed Consent Statement: Not applicable.

Data Availability Statement: Not applicable.

Acknowledgments: This research has been possible through the support of the Texas A\&M Energy Institute Seed Grant Program.

Conflicts of Interest: The authors declare no conflict of interest.

\section{References}

1. UNHCR Figures at a Glance. Available online: https://www.unhcr.org/figures-at-a-glance.html (accessed on 14 August 2021).

2. UNHCR Situation Afghanistan Situation. Available online: https://data2.unhcr.org/en/situations/afghanistan (accessed on 14 August 2021).

3. Council on Foreign Relations Civil War in South Sudan. Available online: https://cfr.org/global-conflict-tracker/conflict/civilwar-south-sudan (accessed on 14 August 2021).

4. UNHCR Situation South Sudan. Available online: https://data2.unhcr.org/en/situations/southsudan (accessed on 14 August 2021).

5. Patra, D. Reducing Energy Cost for Wastewater Treatment in the Middle East: A Physio-chemical Prospective. In Water, Energy E Food Sustainability in the Middle East; Murad, S., Baydoun, E., Daghir, N., Eds.; Springer International Publishing: Cham, Germany, 2017; pp. 223-244. ISBN 978-3-319-48919-3.

6. Rogers, P. The Triangle: Energy, Water \& Food Nexus for Sustainable Security in the Arab Middle East. In Water, Energy E Food Sustainability in the Middle East: The Sustainability Triangle; Baydoun, E., Daghir, N., Murad, S., Eds.; Springer International Publishing: Cham, Germany, 2017; pp. 21-43. ISBN 978-3-319-48920-9.

7. Siddiqi, A.; Anadon, L.D. The Water-Energy Nexus in Middle East and North Africa. Energy Policy 2011, 39, 4529-4540. [CrossRef]

8. Tidey, C.; Boulierac, C. Climate Change Threatens Lives and Futures of over 19 Million Children in Bangladesh. Available online: https:/ / www.unicef.org/press-releases/climate-change-threatens-lives-and-futures-over-19-million-children-bangladesh (accessed on 14 August 2021).

9. Pimentel, D.; Cooperstein, S.; Randell, H.; Filiberto, D.; Sorrentino, S.; Kaye, B.; Nicklin, C.; Yagi, J.; Brian, J.; O’Hern, J.; et al. Ecology of Increasing Diseases: Population Growth and Environmental Degradation. Hum. Ecol. 2007, 35, 653-668. [CrossRef] [PubMed]

10. United Nations. Transforming Our World: The 2030 Agenda for Sustainable Development; United Nations (UN): New York, NY, USA, 2015.

11. Le Blanc, D. Towards Integration at Last? The Sustainable Development Goals as a Network of Targets: The Sustainable Development Goals as a Network of Targets. Sustain. Dev. 2015, 23, 176-187. [CrossRef]

12. Scott, A.; Worrall, L.; Pickard, S. Energy, Migration and the 2030 Agenda for Sustainable Development. Available online: https: //www.greengrowthknowledge.org/sites/default/files/downloads/resource/Energy_migration_2030_ODI.pdf (accessed on 14 August 2021).

13. Sachs, J.; Kroll, C.; Lafortune, G.; Fuller, G.; Woelm, F. Sustainable Development Report 2021, 1st ed.; Cambridge University Press: Cambridge, UK, 2021; ISBN 978-1-00-910655-9. 
14. Daher, B.; Mohtar, R.; Pistikopoulos, E.; Portney, K.; Kaiser, R.; Saad, W. Developing Socio-Techno-Economic-Political (STEP) Solutions for Addressing Resource Nexus Hotspots. Sustainability 2018, 10, 512. [CrossRef]

15. Dubois. The Case for "Energy-Smart Food for People and Climate"; World Food Day; Food and Agriculture Organization of the United Nations: Rome, Italy, 2015.

16. Simpson, G.B.; Jewitt, G.P.W. The Development of the Water-Energy-Food Nexus as a Framework for Achieving Resource Security: A Review. Front. Environ. Sci. 2019, 7, 8. [CrossRef]

17. Garcia, D.J.; You, F. The Water-Energy-Food Nexus and Process Systems Engineering: A New Focus. Comput. Chem. Eng. 2016, 91, 49-67. [CrossRef]

18. Hoff, H. Background Paper for the Bonn2011 Conference: The Water, Energy and Food Security Nexus; Stockholm Environment Institute: Stockholm, Sweden, 2011.

19. Zhang, C.; Chen, X.; Li, Y.; Ding, W.; Fu, G. Water-Energy-Food Nexus: Concepts, Questions and Methodologies. J. Clean. Prod. 2018, 195, 625-639. [CrossRef]

20. World Economic Forum. Global Risks 2011: An Initiative of the Risk Response Network; World Economic Forum: Geneva, Switzerland, 2011; ISBN 978-92-95044-47-0.

21. Gain, A.K.; Giupponi, C.; Benson, D. The Water-Energy-Food (WEF) Security Nexus: The Policy Perspective of Bangladesh. Water Int. 2015, 40, 895-910. [CrossRef]

22. Benson, D.; Gain, A.K.; Rouillard, J.J. Water Governance in a Comparative Perspective: From IWRM to a "Nexus" Approach? Water Altern. 2015, 8, 756-773.

23. Cairns, R.; Krzywoszynska, A. Anatomy of a Buzzword: The Emergence of 'the Water-Energy-Food Nexus' in UK Natural Resource Debates. Environ. Sci. Policy 2016, 64, 164-170. [CrossRef]

24. Allouche, J.; Middleton, C.; Gyawali, D. Technical Veil, Hidden Politics: Interrogating the Power Linkages behind the Nexus. Water Altern. 2015, 8, 610-626.

25. Liu, J.; Yang, H.; Cudennec, C.; Gain, A.K.; Hoff, H.; Lawford, R.; Qi, J.; de Strasser, L.; Yillia, P.T.; Zheng, C. Challenges in Operationalizing the Water-Energy-Food Nexus. Hydrol. Sci. J. 2017, 62, 1714-1720. [CrossRef]

26. Pandey, V.P.; Shrestha, S. Water-Energy-Food Nexus: Principles and Practices. In Evolution of the Nexus as a Policy and Development Discourse; Shrestha, S., Pandey, V.P., Anal, A.K., Eds.; Wiley: Indianapolis, IN, USA, 2017; pp. 11-20.

27. Keskinen, M.; Guillaume, J.; Kattelus, M.; Porkka, M.; Räsänen, T.; Varis, O. The Water-Energy-Food Nexus and the Transboundary Context: Insights from Large Asian Rivers. Water 2016, 8, 193. [CrossRef]

28. Sanders, K.T.; Webber, M.E. Evaluating the Energy Consumed for Water Use in the United States. Environ. Res. Lett. 2012, 7, 034034. [CrossRef]

29. Albrecht, T.R.; Crootof, A.; Scott, C.A. The Water-Energy-Food Nexus: A Systematic Review of Methods for Nexus Assessment. Environ. Res. Lett. 2018, 13, 043002. [CrossRef]

30. Cai, X.; Wallington, K.; Shafiee-Jood, M.; Marston, L. Understanding and Managing the Food-Energy-Water Nexus-Opportunities for Water Resources Research. Adv. Water Resour. 2018, 111, 259-273. [CrossRef]

31. Zelinka, D.; Amadei, B. A Methodology to Model the Integrated Nature of the Sustainable Development Goals: Importance for Engineering Education. In Proceedings of the 2017 ASEE Annual Conference \& Exposition Proceedings, ASEE Conferences, Columbus, OH, USA, 1 June 2017; p. 27479.

32. Nilsson, M.; Griggs, D.; Visbeck, M. Policy: Map the Interactions between Sustainable Development Goals. Nature 2016, 534, 320-322. [CrossRef] [PubMed]

33. FAO. The Water-Energy-Food Nexus: A New Appraoch in Support of Food Security and Sustainable Agriculture; Food and Agriculture Organization of the United Nations: Rome, Italy, 2014.

34. Dai, J.; Wu, S.; Han, G.; Weinberg, J.; Xie, X.; Wu, X.; Song, X.; Jia, B.; Xue, W.; Yang, Q. Water-Energy Nexus: A Review of Methods and Tools for Macro-Assessment. Appl. Energy 2018, 210, 393-408. [CrossRef]

35. Daher, M.; Carré, D.; Jaramillo, A.; Olivares, H.; Tomicic, A. Experience and Meaning in Qualitative Research: A Conceptual Review and a Methodological Device Proposal. Forum Qual. Soz. Forum Qual. Soc. Res. 2017, 18. [CrossRef]

36. Global CLEWS. Available online: https://unite.un.org/sites/unite.un.org/files/app-globalclews-v-1-0/landingpage.html (accessed on 14 August 2021).

37. Stockholm Environment Institute Water Evaluation and Planning. Available online: https://www.sei.org/ (accessed on 14 August 2021).

38. Howells, M.; Hermann, S.; Welsch, M.; Bazilian, M.; Segerström, R.; Alfstad, T.; Gielen, D.; Rogner, H.; Fischer, G.; van Velthuizen, H.; et al. Integrated Analysis of Climate Change, Land-Use, Energy and Water Strategies. Nat. Clim. Chang. 2013, 3, 621-626. [CrossRef]

39. Daher, B.T.; Mohtar, R.H. Water-Energy-Food (WEF) Nexus Tool 2.0: Guiding Integrative Resource Planning and DecisionMaking. Water Int. 2015, 40, 748-771. [CrossRef]

40. Guillaume, J.; Kummu, M.; Eisner, S.; Varis, O. Transferable Principles for Managing the Nexus: Lessons from Historical Global Water Modelling of Central Asia. Water 2015, 7, 4200-4231. [CrossRef]

41. Yang, Y.C.E.; Wi, S.; Ray, P.A.; Brown, C.M.; Khalil, A.F. The Future Nexus of the Brahmaputra River Basin: Climate, Water, Energy and Food Trajectories. Glob. Environ. Chang. 2016, 37, 16-30. [CrossRef] 
42. Martinez-Hernandez, E.; Leach, M.; Yang, A. Understanding Water-Energy-Food and Ecosystem Interactions Using the Nexus Simulation Tool NexSym. Appl. Energy 2017, 206, 1009-1021. [CrossRef]

43. Giampietro, M.; Aspinall, R.; Bukkens, G.F.S.; Cadillo, J.; Diaz-Maurin, F.; Flammini, A.; Gomiero, T.; Kovacic, Z.; Lopez, C.M.; Ramos-Martin, J. An Innovative Accounting Framework for the Food-Energy-Water Nexus: Application of the MuSIASEM Approach to Three Case Studies; Giampietro, M., Ed.; Environment and Natural Resources Management Working Paper Energy; Food and Agriculture Organization of the United Nations: Rome, Italy, 2013; ISBN 978-92-5-107957-7.

44. Trujillo, M.; Food and Agriculture Organization of the United Nations. The Impact of Disasters on Agriculture and Food Security; FAO: Rome, Italy, 2015; ISBN 978-92-5-108962-0.

45. Rising, K.L.; Powell, R.E.; Cameron, K.A.; Salzman, D.H.; Papanagnou, D.; Doty, A.M.B.; Latimer, L.; Piserchia, K.; McGaghie, W.C.; McCarthy, D.M. Development of the Uncertainty Communication Checklist: A Patient-Centered Approach to Patient Discharge From the Emergency Department. Acad. Med. 2020, 95, 1026-1034. [CrossRef] [PubMed]

46. WFP. At the Root of Exodus: Food Security, Conflict and International Migration; World Food Programme: Rome, Italy, 2017.

47. Munshi, K. Networks in the Modern Economy: Mexican Migrants in the U. S. Labor Market. Q. J. Econ. 2003, 118, 549-599. [CrossRef]

48. FAO. World Water Forum 8 | Brasilia, Brasil, 18-23 March 2018. Available online: http://www.faoorg/land-water/events/wwf8 / fr/ (accessed on 15 August 2021).

49. IOM. International Migration Law-Glossary on Migration. 2019. Available online: https://publications.iom.int/system/files / pdf/iml_34_glossary.pdf (accessed on 14 August 2021).

50. United Nations. 2019 Revision of World Population Prospects; World Population Prospects-Population Division: New York, NY, USA. Available online: https:/ / population.un.org/wpp/ (accessed on 14 August 2021).

51. UNHCR. Convention and Protocol Relating to the Status of Refugees: 1951 Convention. 1951. Available online: https://www. unhcr.org/4ae57b489.pdf (accessed on 15 August 2021).

52. European Migration Network. Asylum and Migration Glossary 3.0; European Commission: Brussel, Belgium, 2014.

53. World Economic Forum. Migration and Its Impact on Cities; World Economic Forum: Geneva, Switzerland, 2017.

54. Arous, R. The Predicament of Syrian Refugees in Navigating Cairo's Urban Spaces and the Complexities of Governance in Turbulent Time. 2013. Available online: https://iusd.asu.edu.eg/wp-content/uploads/2015/11/1stInt_Arous.pdf (accessed on 15 August 2021).

55. IDMC. Global Report on Internal Displacement; Norwegian Refugee Council: Geneva, Switzerland, 2016.

56. Sarzin, Z. Stocktaking of Global Forced Displacement Data; World Bank's Global Program on Forced Displacement: Washington DC, USA, 2017.

57. Davis, K.F.; Bhattachan, A.; D'Odorico, P.; Suweis, S. A Universal Model for Predicting Human Migration under Climate Change: Examining Future Sea Level Rise in Bangladesh. Environ. Res. Lett. 2018, 13, 064030. [CrossRef]

58. Nagabhatla, N.; Pouramin, P.; Brahmbhatt, R.; Fioret, C.; Glickman, T.; Bruce Newbold, K.; Smakhtin, V. Water and Migration: A Global Overview; UNU-INWEH; United Nations University Institute for Water, Environment and Health: Hamilton, ON, Canada, 2020; Volume 10, ISBN 978-808-6102-0.

59. The Aral Sea Disappears While Tuberculosis Climbs. Available online: https://www.msf.org/aral-sea-disappears-whiletuberculosis-climbs (accessed on 15 August 2021).

60. Gleick, P.H. Water, Drought, Climate Change, and Conflict in Syria. Weather Clim. Soc. 2014, 6, 331-340. [CrossRef]

61. Jaafar, H.; Ahmad, F.; Holtmeier, L.; King-Okumu, C. Refugees, Water Balance, and Water Stress: Lessons Learned from Lebanon. Ambio 2020, 49, 1179-1193. [CrossRef]

62. Müller, M.F.; Yoon, J.; Gorelick, S.M.; Avisse, N.; Tilmant, A. Impact of the Syrian Refugee Crisis on Land Use and Transboundary Freshwater Resources. Proc. Natl. Acad. Sci. USA 2016, 113, 14932-14937. [CrossRef]

63. Pachauri, S.; van Ruijven, B.J.; Nagai, Y.; Riahi, K.; van Vuuren, D.P.; Brew-Hammond, A.; Nakicenovic, N. Pathways to Achieve Universal Household Access to Modern Energy by 2030. Environ. Res. Lett. 2013, 8, 024015. [CrossRef]

64. Muñoz, H.M. The Role of Sustainable Energy Access in the Migration Debate; European Union Energy Initiative Partnership Dialogue Facility: Eschborn, Germany, 2017; Available online: https://www.idaea.csic.es/sites/default/files/EU-Energy-Initiativeworking_paper_the_role_of_sustainable_energy_access_in_the_migration_debate.pdf (accessed on 14 August 2021). [CrossRef]

65. Ratha, D. How Will Falling Oil Prices Affect Remittances? Available online: https://www.weforum.org/agenda/2015/01/howwill-falling-oil-prices-affect-remittances / (accessed on 15 August 2021).

66. Parveen, S.; Faisal, I.M. People versus Power: The Geopolitics of Kaptai Dam in Bangladesh. Int. J. Water Resour. Dev. 2002, 18, 197-208. [CrossRef]

67. The Global Plan of Action for Sustainable Energy Solutions in Situations of Displacement. 2018. Available online: https: //unitar.org/sites/default/files/media/file/gpa_framework_final-compressed.pdf (accessed on 15 August 2021).

68. Balduzzi, S.; Rücker, G.; Schwarzer, G. How to Perform a Meta-Analysis with R: A Practical Tutorial. Evid. Based Ment. Health 2019, 22, 153-160. [CrossRef] [PubMed]

69. Van Trotsenburg, A. Facing an Unprecedented Migration Crisis in Latin America and the Caribbean. Available online: https:/ / www.worldbank.org/en/news/opinion/2019/03/29/america-latina-y-el-caribe-frente-a-una-crisis-migratoria-sinprecedentes (accessed on 15 August 2021). 
70. Da Silva, J.G.; Shenggen, F. Conflict, Migration and Food Security: The Role of Agriculture and Rural Development. 2017. Available online: http:/ / www.fao.org/3/i7896e/i7896e.pdf (accessed on 16 August 2021).

71. Hoddinott, J.F. Agriculture, Health, and Nutrition: Toward Conceptualizing the Linkages. In Reshaping Agriculture for Nutrition and Health; Fan, S., Pandya-Lorch, R., Eds.; 2020 Conference Book; International Food Policy Research Institute (IFPRI): Washington, DC, USA, 2012; Volume 2, pp. 13-20.

72. Ravenstein, E.G. The Laws of Migration. J. Stat. Soc. Lond. 1885, 48, 167. [CrossRef]

73. Dharmadasa, R.A.; Herath, H.M. Determinants of International Migration to Middle-East Countries-Gravity Model Approach; University of Colombo: Colombo, Sri Lanka, 2018; pp. 68-88.

74. Mayda, A.M. International Migration: A Panel Data Analysis of the Determinants of Bilateral Flows. J. Popul. Econ. 2010, 23, 1249-1274. [CrossRef]

75. Poot, J.; Alimi, O.; Cameron, M.P.; Mare, D.C. The Gravity Model of Migration: The Successful Comeback of an Ageing Superstar in Regional Science. Investig. Reg. 2016, 36, 63-86.

76. Simini, F.; González, M.C.; Maritan, A.; Barabási, A.-L. A Universal Model for Mobility and Migration Patterns. Nature 2012, 484, 96-100. [CrossRef]

77. Alburez-Gutierrez, D.; García, C.S. The UNHCR Demographic Projection Tool: Estimating the Future Size and Composition of Forcibly Displaced Populations. 2018, Volume 22. Available online: https:/ /www.unhcr.org/5ae9ee747.pdf (accessed on 15 August 2021).

78. Robinson, C.; Dilkina, B. A Machine Learning Approach to Modeling Human Migration. In Proceedings of the 1st ACM SIGCAS Conference on Computing and Sustainable Societies, ACM, Menlo Park and San Jose, CA, USA, 20 June 2018; pp. 1-8.

79. Groen, D.; Bhati, A.P.; Suter, J.; Hetherington, J.; Zasada, S.J.; Coveney, P.V. FabSim: Facilitating Computational Research through Automation on Large-Scale and Distributed e-Infrastructures. Comput. Phys. Commun. 2016, 207, 375-385. [CrossRef]

80. Klüpfel, H.; Schreckenberg, M.; Meyer-König, T. Models for Crowd Movement and Egress Simulation. In Traffic and Granular Flow '03; Hoogendoorn, S.P., Luding, S., Bovy, P.H.L., Schreckenberg, M., Wolf, D.E., Eds.; Springer: Berlin/Heidelberg, Germany, 2005; pp. 357-372. ISBN 978-3-540-25814-8.

81. Klabunde, A. Computational Economic Modeling of Migration; Chen, S.-H., Kaboudan, M., Du, Y.-R., Eds.; Oxford University Press: Oxford, UK, 2018; Volume 1.

82. Lin, L.; Carley, K.M.; Cheng, S.-F. An Agent-Based Approach to Human Migration Movement. In Proceedings of the Research Collection School of Information Systems, Arlington, VA, USA, 11 December 2016; pp. 3150-3520.

83. Hassani-Mahmooei, B.; Parris, B.W. Climate Change and Internal Migration Patterns in Bangladesh: An Agent-Based Model. Environ. Dev. Econ. 2012, 17, 763-780. [CrossRef]

84. Sokolowski, J.A.; Banks, C.M. A Methodology for Environment and Agent Development to Model Population Displacement. Simul. Ser. 2014, 46, 17-27.

85. Suleimenova, D.; Bell, D.; Groen, D. A Generalized Simulation Development Approach for Predicting Refugee Destinations. Sci. Rep. 2017, 7, 13377. [CrossRef]

86. De Kock, C. A Framework for Modelling Conflict-Induced Forced Migration According To An Agent-Based Approach. 2019. Available online: https:/ / scholar.sun.ac.za/handle/10019.1/107038 (accessed on 15 August 2021).

87. Klabunde, A.; Willekens, F. Decision-Making in Agent-Based Models of Migration: State of the Art and Challenges. Eur. J. Popul. 2016, 32, 73-97. [CrossRef]

88. OECD; EASO. Can We Anticipate Future Migration Flows? Migration Policy Debates 2018. Available online: https://www.oecd. org/els/mig/migration-policy-debate-16.pdf (accessed on 14 August 2021).

89. Hébert, G.A.; Perez, L.; Harati, S. An Agent-Based Model to Identify Migration Pathways of Refugees: The Case of Syria. In Agent-Based Models and Complexity Science in the Age of Geospatial Big Data; Perez, L., Kim, E.-K., Sengupta, R., Eds.; Advances in Geographic Information Science; Springer International Publishing: Cham, Germany, 2018; pp. 45-58. ISBN 978-3-319-65992-3.

90. Hillman, J.R.; Baydoun, E. Food Security in an Insecure Future. In Water, Energy \& Food Sustainability in the Middle East: The Sustainability Triangle, 1st ed.; Baydoun, E., Daghir, N., Murad, S., Eds.; Springer International Publishing: Cham, Germany, 2017; pp. 261-282. ISBN 978-3-319-48920-9.

91. 1918 Pandemic (H1N1 Virus) | Pandemic Influenza (Flu) | CDC. Available online: https:/ / www.cdc.gov/flu/pandemic-resources / 1918-pandemic-h1n1.html (accessed on 14 August 2021).

92. Social and Economic Impacts of the 1918 Influenza Epidemic. Available online: https:/ /www.nber.org/digest/may20/socialand-economic-impacts-1918-influenza-epidemic (accessed on 14 August 2021).

93. COVID Data Tracker. Available online: https:/ / covid.cdc.gov/covid-data-tracker (accessed on 14 August 2021).

94. Bureau of Labor Statistics. The Employment Situation; U.S. Department of Labor: Washington, DC, USA, 2020 ; p. 42.

95. Water-Related Diseases and Contaminants in Public Water Systems | Public Water Systems I Drinking Water I Healthy Water. Available online: https://www.cdc.gov/healthywater/drinking/public/water_diseases.html (accessed on 14 August 2021).

96. Drinking-Water. Available online: https:/ /www.who.int/news-room/fact-sheets/detail/drinking-water (accessed on 14 August 2021).

97. Great Lakes Community Action Partnership Pandemic Continuity of Operations Plan Template. Available online: https: //www.glcap.org/media/2569/pandemic-continuity-of-operations-plan-template.pdf (accessed on 14 August 2021).

98. Oil-Global Energy Review 2020—Analysis. Available online: https:/ / www.iea.org/reports/global-energy-review-2020/oil (accessed on 14 August 2021). 
99. Fry, W.E.; Goodwin, S.B. Resurgence of the Irish Potato Famine Fungus. BioScience 1997, 47, 363-371. [CrossRef]

100. Cagle, S. "A Disastrous Situation": Mountains of Food Wasted as Coronavirus Scrambles Supply Chain. The Guardian, 9 April 2020.

101. Fortune, A. US Meat Supply under Threat from Coronavirus. Available online: https://www.foodnavigator-usa.com/Article/20 20/05/06/US-meat-supply-under-threat-from-coronavirus (accessed on 14 August 2021).

102. Huppert, A.; Katriel, G. Mathematical Modelling and Prediction in Infectious Disease Epidemiology. Clin. Microbiol. Infect. 2013, 19, 999-1005. [CrossRef] [PubMed]

103. Savary, S.; Stetkiewicz, S.; Brun, F.; Willocquet, L. Modelling and Mapping Potential Epidemics of Wheat Diseases-Examples on Leaf Rust and Septoria Tritici Blotch Using EPIWHEAT. Eur. J. Plant Pathol. 2015, 142, 771-790. [CrossRef]

104. Eriksen, L.; Shaw, M.W.; Østergård, H. A Model of the Effect of Pseudothecia on Genetic Recombination and Epidemic Development in Populations of Mycosphaerella Graminicola. Phytopathology 2001, 91, 240-248. [CrossRef]

105. He, S.; Creasey Krainer, K.M. Pandemics of People and Plants: Which Is the Greater Threat to Food Security? Mol. Plant 2020, 13, 933-934. [CrossRef] [PubMed]

106. Huff, A.G.; Beyeler, W.E.; Kelley, N.S.; McNitt, J.A. How Resilient Is the United States' Food System to Pandemics? J. Environ. Stud. Sci. 2015, 5, 337-347. [CrossRef]

107. Hurricane Florence I Natural Disasters and Severe Weather. Available online: https://www.cdc.gov/disasters/index.html (accessed on 14 August 2021).

108. Natural Disasters. Available online: https:/ /www.dhs.gov/natural-disasters (accessed on 14 August 2021).

109. Manners-Bell, J. Supply Chain Risk: Understanding Emerging Threats to Global Supply Chains; Kogan Page: London, UK, 2014; ISBN 978-0-7494-7110-1.

110. Farooq, M.; Rehman, A.; Pisante, M. Sustainable Agriculture and Food Security. In Innovations in Sustainable Agriculture; Farooq, M., Pisante, M., Eds.; Springer International Publishing: Cham, Germany, 2019; pp. 3-24. ISBN 978-3-030-23169-9.

111. UN-Water Disasters. Available online: https://www.unwater.org/water-facts/disasters/ (accessed on 16 August 2021).

112. Farukh, M.; Hossen, M.; Ahmed, S. Impact of Extreme Cyclone Events on Coastal Agriculture in Bangladesh. Progress. Agric. 2019, 30, 33-41. [CrossRef]

113. UNHCR Situation Syria Regional Refugee Response. Available online: https: / / data2.unhcr.org/en/situations / syria\#_ga=2.1890 22831.57899013.1589743744-793005486.1586112362 (accessed on 14 August 2021).

114. Femia, F.; Werrell, C. Syria: Climate Change, Drought and Social Unrest. Available online: https://climateandsecurity.org/2012 /02/syria-climate-change-drought-and-social-unrest/ (accessed on 15 August 2021).

115. Galbusera, L.; Giannopoulos, G. On Input-Output Economic Models in Disaster Impact Assessment. Int. J. Disaster Risk Reduct. 2018, 30, 186-198. [CrossRef]

116. Botzen, W.J.W.; Deschenes, O.; Sanders, M. The Economic Impacts of Natural Disasters: A Review of Models and Empirical Studies. Rev. Environ. Econ. Policy 2019, 13, 167-188. [CrossRef]

117. Israel, D.C.; Briones, R.M. Impacts of Natural Disasters on Agriculture, Food Security, and Natural Resources and Environment in the Philippines; PIDS Discussion Paper Series; ERIA: Jakarta, Indonesia, 2012.

118. Ainehvand, S.; Raeissi, P.; Ravaghi, H.; Maleki, M. Natural Disasters and Challenges toward Achieving Food Security Response in Iran. J. Educ. Health Promot. 2019, 8, 51. [CrossRef]

119. Brabant, M. At Greek Refugee Camp, There Are Few Defenses against COVID-19 Threat. Available online: https://www.pbs org/newshour/show / at-greek-refugee-camp-there-are-few-defenses-against-covid-19-threat (accessed on 14 August 2021).

120. Blackburn, C.C.; Lenze, P.E. Forced Migration and the Spread of Infectious Disease: Impact of Syrian Refugee Movements on Disease Prevalence in the European Union. 2017. Available online: https:/ / oaktrust.library.tamu.edu/bitstream/handle/1969.1 /165005/Paper\%20No.\%2010\%20Blackburn\%20\%26\%20Lenze.pdf?sequence=1\&isAllowed=y (accessed on 14 August 2021).

121. McMichael, C. Climate Change-Related Migration and Infectious Disease. Virulence 2015, 6, 548-553. [CrossRef]

122. Boyce, B. Pandemics Aren't Just for People: How Disease Can Affect Crops and the Food Supply. J. Am. Diet. Assoc. 2010, 110, 18-24. [CrossRef]

123. Gayer, M.; Legros, D.; Formenty, P.; Connolly, M.A. Conflict and Emerging Infectious Diseases. Emerg. Infect. Dis. 2007, 13, 1625-1631. [CrossRef]

124. Mackinnon, M. Fears Rise about an Unstoppable Coronavirus Outbreak in Refugee Camps in Greece. The Globe and Mail, 3 April 2020.

125. Friedrich, M.J. Vaccination Effort Targets Middle East After Polio Outbreak in Syria. JAMA 2013, 310, 2497. [CrossRef]

126. Leblebicioglu, H.; Ozaras, R. Syrian Refugees and Infectious Disease Challenges. Travel Med. Infect. Dis. 2015, 13, 443-444. [CrossRef]

127. United Nations; Department of Economic and Social Affairs; Population Division. International Migration 2019: Report; UNDESA: New York, NY, USA, 2019; ISBN 978-92-1-148338-3.

128. Ghoshal, D.; Jadhav, R. India's Urban COVID-19 Outbreak Is Morphing into a Rural Health Crisis. Reuters, 4 June 2020.

129. UNHCR. A Handy Guide to UNHCR Emergency Standards and Indicators 2000. Available online: https://www.refworld.org/ pdfid/3dee456c4.pdf (accessed on 14 August 2021).

130. Grineski, S.E.; Flores, A.B.; Collins, T.W.; Chakraborty, J. Hurricane Harvey and Greater Houston Households: Comparing Pre-event Preparedness with Post-event Health Effects, Event Exposures, and Recovery. Disasters 2020, 44, 408-432. [CrossRef] 
131. Schwartz, R.; Tuminello, S.; Kerath, S.; Rios, J.; Lieberman-Cribbin, W.; Taioli, E. Preliminary Assessment of Hurricane Harvey Exposures and Mental Health Impact. IJERPH 2018, 15, 974. [CrossRef]

132. Watson, J.T.; Gayer, M.; Connolly, M.A. Epidemics after Natural Disasters. Emerg. Infect. Dis. 2007, 13, 1-5. [CrossRef]

133. Byrne, K. Amphan Turns Deadly as It Causes Widespread Damage across India, Bangladesh. MSN, 20 May 2020.

134. Farmers in Flood-Hit Areas Need Urgent Protection. The Daily Star, 2 July 2020.

135. IANS Cyclone Amphan Causes Damages Worth 978 Crore Rupees in Bangladesh I The Weather Channel. Available online: https: / / weather.com/en-IN/india/news/news/2020-05-22-bangladesh-faces-loss-worth-crore-super-cyclonic-storm-amphan (accessed on 14 August 2021).

136. Ferguson, S. Cyclone Amphan Makes Landfall During Coronavirus Pandemic. UNICEF, 20 May 2020.

137. Oxfam Australia "Crisis on Top of Crisis" as India and Bangladesh Brace for Cyclone Amphan-Oxfam I Mirage News. Available online: https: / www.miragenews.com/crisis-on-top-of-crisis-as-india-and-bangladesh-brace-for-cyclone-amphan-oxfam (accessed on 14 August 2021).

138. Ministry of Agriculture Amphan Affected Farmers Will Be Supported with Free Fertilizers, Seeds, Cash and Other Supplementary 2020. Available online: https:/ / reliefweb.int/sites/reliefweb.int/files/resources/Iraq\%20Agriculture\%20Sector\%20Note.pdf (accessed on 1 June 2021).

139. Chayan, I. Preventing the Spread of COVID-19 in Rohingya Camps. Caritas, 26 June 2020.

140. Berlemann, M.; Steinhardt, M.F. Climate Change, Natural Disasters, and Migration-A Survey of the Empirical Evidence. CESifo Econ. Stud. 2017, 63, 353-385. [CrossRef]

141. African Development Bank Group; Mbaye, L. Climate Change, Natural Disasters, and Migration. IZA World Labor 2017, 346, 1-10. [CrossRef]

142. Oxfam The Hunger Virus Multiplies: Deadly Recipe of Conflict, COVID-19, and Climate Accelerate World Hunger 2021. Available online: https: / / oi-files-d8-prod.s3.eu-west-2.amazonaws.com/s3fs-public/2021-07/The\%20Hunger\%20Virus\%202.0_media\% 20brief_EN.pdf (accessed on 16 August 2021). 